\title{
Mechanism of Investment Maintenance for the Sustainable Development of the Agraricultural Sphere
}

\author{
Reznik N.P, DemyanYa.Yu, Tokar Ya.I, Sandeep Kumar Gupta, Anatoliy D. Ostapchuk
}

\begin{abstract}
The article considers mechanism of investment maintenance of sustainable development of the agricultural sphere which should be based on a set of principles, measures and tools that ensure the flow of income and efficient use of investment resources by joint interaction, ultimately enable sustainable development of the agricultural sphere as an integral socio - economic system on the basis of human - centrated basis, differentiated zonal approach, alignment of territorial asymmetry, deepening cross-border cooperation, focus on European standards, ensure effective competition, development of entrepreneurship, reorienting development criteria and indirect state intervention.
\end{abstract}

Keywords: Sustainable Development, Agriculture, Investment Maintenance, Investment Maintenance Mchanism

Achieving sustainable development trends of the agricultural sphere requires a revival of investment processes from all the sources of funding and strengthening investment activity of economic entities. Therefore, finding the ways to ensure the sustainable development of the agricultural sphere should begin with solving the problem of investment maintenance, which has become an important task of modern economic science.

\section{ANALYSIS OF THE LATEST RESEARCHES AND PUBLICATIONS.}

Various aspects of the socio-economic development of the national economy, including the agricultural sphere, are covered in the works of A.V.Balyan, A V.G. Andriychuk, V.S. Diesperova, S. M. Kvasha, M. D. Kondratiev, Yu. O. Lupenko, M. Y. Malik, K. Marx, V. Ya. Mesel-Veselyak, M. I. Pugacheva, V P. P. Ryabokonya, P. T. Sabluk, M. P. Talaviri.

Revised Manuscript Received on September 10, 2019.

Reznik N.P, Professor; National University of Life and Environment Science of Ukraine, Europe.

(Email: nadya-reznik@ukr.net)

DemyanYa.Yu, Asosiated Professor, Mukachevo State University, Ukraine, Europe.

(Email: yaroslavademyan88@gmail.com)

Tokar Ya.I, PhD,Mukachevo State Universitie, Ukraine, Europe.

(Email: yaryna.tb90@gmail.com) India.

(Email: skguptabhu@gmail.com)

Anatoliy D. Ostapchuk, Associate Professor; National University of Life and Environment Sciences of Ukraine, Europe.

(Email: aostapchuk@ukr.net)

\section{FORMULATION OF THE PROBLEM}

Sandeep Kumar Gupta, Professor; Sharda University, Greater Noida

\section{IDENTIFICATION OF PREVIOUSLY UNSETTLED ISSUES OF THE GENERAL PROBLEM.}

The mechanism of the investment maintenance, which is a set of principles, measures and instruments, that in general cooperation assist the accumulation of investment resources from all the possible sourcings, their investment and the effective use in the different segments of agraricultural sphere, must become the basis of the realization of politics of sustainable development, that in an eventual result will provide its development as an integral socio-economic system on human-centered basis.

\section{FORMULATION THE GOALS OF THE RESEARCH}

The purpose of the article is to deepen theoretical principles and to provide scientific substantiation of practical proposals regarding the investment mainteness of sustainable development of the agricultural sphere.

\section{RESEARCH METHODS AND MATERIAL \& RESULTS}

Sustainable development of the agricultural sphere is the basis for food and national security of the state, development of other industries and other sectors of economy,activation of the Ukrainian agraricultural commodi ty producers on world markets and also solving a number of social and economic problems of the rural population.There for its achievement requires formation on special terms and involvement of a number of specific factors. However, a key place in that system of factors should be given to the investment maintanance of sustainable development. By its nature "investment maintenance of sustainable development of the agricultural sphere" is a process of accumulation of investment resources from all possible sources and directing them in time in optimal quantity, quality and proportions to the different segments of the agricultural sphere in order to achieve its development as an integrated system. Investment maintanance requires the creation of favorable conditions by improving legislation, transparency in decision-making by public authorities and local governments, deregulation of business and investment activity, development of investment and financial markets, improvement informative management, development of science, improvement of investment infrastructure etc.

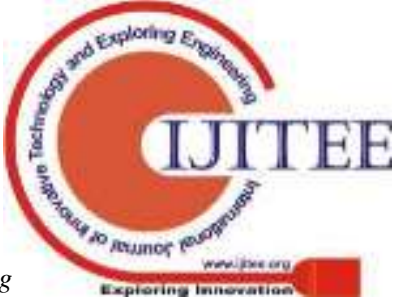


Assessment of the sustainable development of the agricultural sphere and the effectiveness of investment support for this process should be done using a set of indicators on the analysis of economic, environmental and social components of development, in particular: the volume of investments, meeting the needs of business entities, investment opportunities of producers and investors, the dynamics of innovation implementation economic activity, share of production of organic products, dynamics and incomes of rural population, indicators development of the social sphere of the village and rural territories. The integral index of rural settlements development, which includes the assessment of investments in the improvement of the territories and equipment of the housing stock, should play an important role in this system of indicators. An additional assessment indicator should be the modified rural development index, which includes an assessment of the rural population's provision of services and infrastructure and social facilities.

The mechanism of the investment maintanance must become the basis of realization of politics of sustainable development of the agraricultural sphere. The mechanism of the investment maintenance, is a set of principles, measures and instruments, that in general cooperation assist the accumulation of investment resources from all possible sourcings, their investment and the effective use in the different segments of agraricultural sphere, must become the basis of realization of politics of sustainable development, that in an eventual result will provide its development as an integral socio-economic system on human-centered basis.

There is proposed investment maintanance mechanism for sustainable development of the agricultural sphere Figure-1

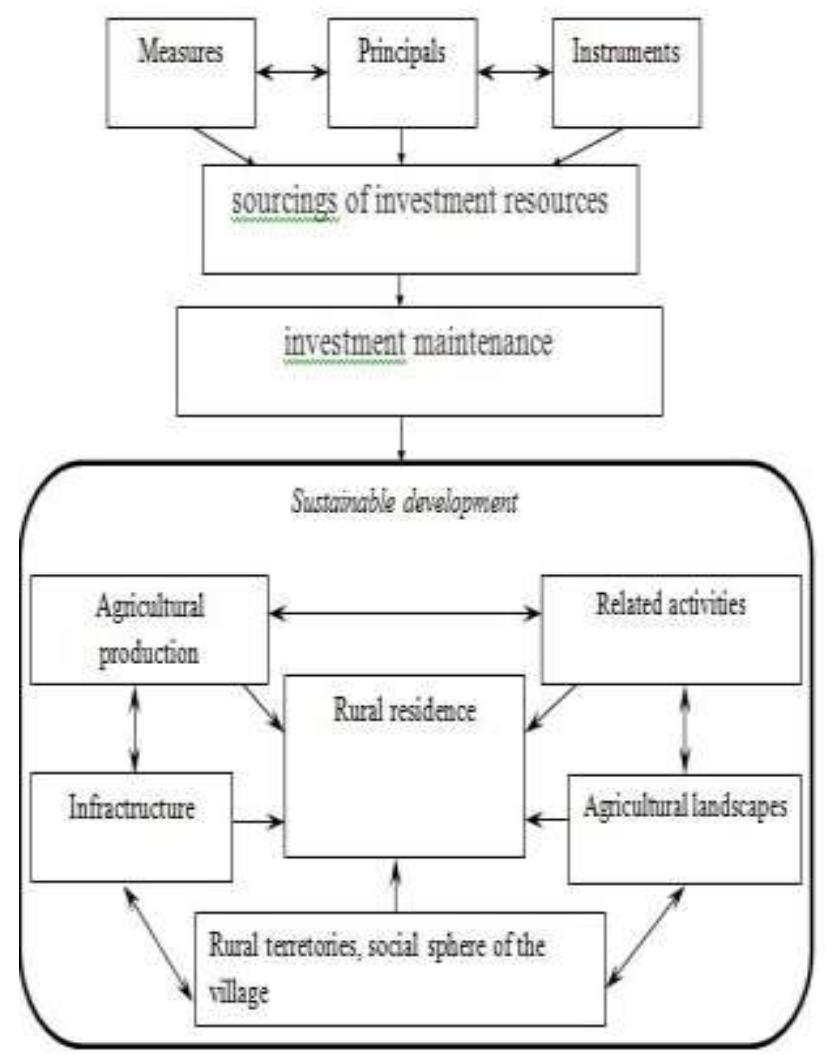

Fig. 1. Schematic representation of the mechanism of investment maintenance of sustainable development of the agraricultural sphere
The main principles of the implementation of the mechanism of investment maintenance of sustainable development of the agraricultural sphere must be:

1. System integrity

2. Human-centrism

3. Differentiated zonal approach

4. Alignment of territorial asymmetry

5. Deepening cross-border cooperation

6. Focus on European standards

7. Ensure effective competition

8. Development of entrepreneurship

9. Reorientation of the development criteria

10. Indirect government support.

The principle of the system integrity is based on the fact that the agricultural sphere is a set of internally connected system elements - agricultural production and related activities, infrastructure, human capital and agricultural landscapes. Their separated development will be more complicated. In fact it is impossible to develop agricultural production effectively with out the infrastructure development, when there are no conditions for the procurement, storage, transportation, primary processing of agricultural products. As well it is hard to achieve productional development by disseminating innovative products, introduction of modern science and technology where there is no human capital, when workers are not prepared to use new, technically advanced production facilities, do not have the appropriate qualifications, do not possess the necessary skills. The development of agricultural and social infrastructures in rural areas are only possible when agricultural production is developing in villages and enouph amount of population live there. One can identify many connections that demonstrate the need for simultaneous integrated development of various segments of the agricultural sphere. All of them indicate that investment projects in various segments of the agricultural sphere should have complementary nature when the realization of one of them increases the effectiveness of others, expand financial sources and optimize cash flows in them. It is therefore necessary to ensure the flow of investments and their effective use in every segment of the agricultural sphere, that is actually what the implementation of the principle of system integrity is about.

Sufficiently often in scientific researches about the problems of sustainable development when grounding the principals of sustainable development scientists put its production in chapter angle. Thus the aim of its development is determined to be the efficiency of the economy, rationalization of resources use, strengthening food security, population provision with quality food, strengthening export potential of agricultural production, improving the competitiveness of producers in agriculture sector etc. In other words development should ensure the solution of the main problems of the government and business. We believe this approach is unacceptable. Nowardays a human must stay in the central link of the problem of sustainable development, and the development is

Published By: 
to be aimed to solve the problems of a human - improving the standarts of life of rural residents, their working conditions, increasing yield and there material wellfare, providing human life in the harmony with nature and the surrounding world. That is why the key principle of the mechanism of investment maintenance of sustainable development of the agricultural sphere should be humancentrism, and investments should be directed to the development of human capital and other areas that contribute to this.

The principle of differentiated zonal approach is important because of the significant differences in the composition and structure of agricultural production, the terms of its transaction, the specific life of rural residents and because of the functioning agricultural sphere in the lowland, foothill and mountain areas of Ukraine. It is based on the need of zonal differentiation principles of investment maintanance and provides policy of bringing in investments to align regional asymmetry of social and economic development.

Thus, the policy of sustainable development of the agricultural sphere in low-lying areas first of all should be directed to the expansion of agricultural business and improving production. It is advisable to promote the development of large settlements and futher transformation them in to cities or big urban settlements. It is possible to increase the distance between places of residence and work of employees of the agricultural sector, while residents of cities, towns or suburbs work in large livestock complexes or cultivate large tracts of agricultural land through hightechnological production facilities. At the same time agricultural production is to gravitate to large-scale type and its main directions will become industrial poultry, breeding, development of large livestock farms, etc.

The politic of sustainable development in the low -laying areas and especially the mountainous areas should be fundamentally different and should be derected to expansion of agricultural business and improvement of its production It is inappropriate to promote conglomerations of settlements because of relief and climatic features. Policy of sustainable development should be directed to the development of social infrastructure, distribution of rural green tourism, taking up non-traditional activities and employments. It is advisable to develop small-scale type of agricultural production and promising areas of the agricultural business should become: honey production, fish farming, and cultivation of organic products, the production of the entire range of goat and sheep products.

Along with it there is a need to create the differentiation approach of the investment maintanance of sustainable development in the steppe, forest - woodlands and broad leaves zones of Ukraine in order to stimulate different areas of agriculture and rural types of settlements. General principle of differentiated zonal approach has become an important element of the mechanism of investment maintenance of the sustainable development of agraricultural sphere of Ukraine. It is coursed by the difference in production and business activities, mentality of people, environment and agricultural landscapes. This requires a differentiated approach for agricultural sphere

development in different climatic zones, areas, regions of Ukraine.

The principle of territory alignment asymmetry is in some ways connected with the above principles of differentiated zonal approach. But he gained urgency because of the fact that in addition to weather and climate, relief and other natural factors the development of rural territory and agricultural production sphere is influenced by social and productional factors. Thus, in one zone can function areas that differ in potential of agricultural production, its competitiveness, efficiency, and are characterized by significant differences in entrepreneurship and initiative of residents, threir living conditions etc. It is necessary to align the development of such areas. There for it is important to identify the causes of regional disparities and take steps to overcome the asymmetry for "point approach" - to use sanctions on those segments of the agricultural shpere which causes territorial asymmetry.

An important principle of investment maintenance of the sustainable development of agricultural sphere and at the same time an instument for fundraising is the development of cross-border cooperation. It is called to provide the distribution of international investment programs and projects in

Ukraine.

Realization of this principle will accelerate Ukraine's integr ation into the global and European economic space, contribute to the spread of European standards inbusiness activity in the domestic agricultural sphere, development of human capital and rural terretories, will provide joint efforts of cross-border cooperation for effective solutions of the common problems of border regions.

This principle is important for all border areas of our country. Ukraine has land borders with seven countries; it includes 19 border administrative units. In the following border regions of Volyn, Ivano-Frankivsk, Lviv, Luhansk, Odessa, Sumy, Kharkiv, Chernivtsi, Chernihiv was established eight European regions - Bug, Upper Prut, Dnieper, Carpathian, Lower Danube, Sloboda, Donbass and Yaroslavna. The problems related to the national-directional management of the border areas of the eastern region of the country which were not solved were one of the catalysts of the military conflict in the East named ATO. This confirms the importance of the principle of cross-border cooperation.

However, in each of the Ukraine's border terretories the development of cross-border cooperation should be based on the regional features and approaches ofmutual relations with neighboring countries? At the same time the main feacher for all the border terretories is that the international cooperation must first of all protect Ukraine's national interests and promote good neighborly relations with other countries.

The development of cross-border cooperation will allow realizing another investment principle of sustainable development of agraricultural sphere which is the principle of orientation to European standards. It means the need for increasing the part of main types of material and nonmaterial resources which will be involved for investment in 
agricultural production, infrastructure and social sphere of the village for European standards. This applies primarily to engineering, technology, seed and planting materials, animal breeds and birds, plant protection, fertilizers etc. In addition, sustainable development criteria should be to achieve European standards of agricultural production and the standart of living of the rural residents.

It is necessary to reorient the criteria of sustainable development, what is another principle about. This updated criteria for development should be not only the improvement of technical and technological, financial, economic, institutional framework of the agricultural production, but also the development of social and environmental segments of the agricultural sphere that will improve working conditions, quality and standard of living of rural residents and eventually ensure the revival of the Ukrainian village as a unique social phenomena with deep socio-cultural and historical traditions.

In market conditions sustainable economic development of agricultural production is possible only in the condition of the creation of an effective competitive environment whith spheres of influence and activities distribution between large agrarian forming and small and medium businesses in the villages. Nowadays there is often a situation when small agricultural producers are competing with large agricultural holding structures, producing the same products. In the case the small producers have no chance to winn in the competition. Giving the importance to the development of large-scale production, significant innovation and investment potential of agricultural holdings and high efficiency of their activities, it is essential to promote the future development of the agro-industrial units .

It is necessary to support and develop small and mediumsized enterprises, focusing the entrepreneurs on the production of those products which require significant labor costs, are unique or require specific growing conditions, are better to be created in small sized enterprises, farms or personal subsidiary farms. In this case, competition will develop within the appropriate segment groups - large enterprises will compete with large enterprises and shallow and medium businesses with each other. This approach will increase the efficiency of management, effective use of resources, better fulfilling the needs of consumers of agricultural products and so on. There is a need to develop entrepreneurial initiative and step up investment flows from private sources what also is an important investment principle of sustainable development of the agricultural sphere. After all, no state, no matter how perfect was its regulatory policy, is unable to achieve the development of the national economy in general and particulary the agricultural sector alone. Such processes are provided only by the businessand the public activity, through the development of entrepreneurship, social movements spreading and development of public initiatives, uploading citizens to solving social problems, democratization of society etc. Also, the main investment flows, as it has been already noted, have to be formed from private, not from government sources.

State intervention in the investment process of maintenance of sustainable development of the agricultural sphere should be primarily based on the principle of indirect government support through the creation favorable investment environment, improvement rules and conditions of business through the development of institutions of the agricultural investment markets etc. Direct and indirect financial participation of the state is needed only by those investment projects whose implementation by private capital is difficult or impossible.

The main leverages of state influence should be:

National Bank of Ukraine rate regulation in order to influence on credit maintanance of investment activity;

Banking system stabilization in order to provide effective accompaniment of investment projects;

Exchange rate stabilization in order to enhance the inflow of foreign investments and expansion of external economic orientation for foreign investment projects;

Taxes optimization and tax pressure reduction for agricultural producers and agricultural investors in order to improve the business environment;

Optimization of customs and tariff regulation with the requirements of the WTO and the international treaties of Ukraine in order to protect the domestic markets from the adverse effects of foreign intervention producers, to protect domestic agricultural business and to promote the competitiveness of Ukrainian farmers in the domestic and international markets;

Target-oriented approach of stimulating of the investment in agricultural sphere and others.

The last of the leveragage of state influence mentioned above is directly related with the instruments of the mechanism of investment maintenance of sustainable development of the agricultural sphere. It is advisible to include to the list of such a special instruments:

National development program of agraricultural sphere;

Regional development programs of the agricultural sphere;

Programs of cross-border cooperation in the agricultural sphere;

Programs of alignment of territory asymmetry;

Industral agricultural investment projects;

Agricultural investment projects of economic entities;

Private investment projects of rural residents.

The main measures of the implementation of the proposed mechanism of investment maintenance of sustainable development of the agraricultural sphere are:

The creation of favorable conditions for entrepreneurship; Fighting against corruption;

The development of legislative initiatives;

Stabilization and further development of investment and financial markets;

Improving the institutional environment;

Protection of the rights of the subjects of the agricultural shpere;

Development of public-private partnership in social and environmental sectors;

-Investment in distribution network of neighboring
Blue Eyes Intelligence Engineering

\& Sciences Publication 
countries in order to sale Ukrainian agricultural products abroad;

The creation of a Regional Fund of support etc.

The realization of the offered mechanism of the investment maintenance of sustainable development will allow to accumulate the investment resources from all the possible sourcings, provide their effective use in the different segments of agraricultural sphere and will ensure its integral sustainable socio-economic development.

In the long run the result of the proposed mechanism will be the technical and technological reequipment of all the sectors of agricultural production. In the crop fields one can expect the improvement of technologies, rational combination of organic and mineral fertilizers, the use of soil technology systems that take into account the peculiarities of soils and landscapes, and are adapted to the climatic specifics zones, areas and regions, the introduction of modern saintifically-based plant protection system and innovative approaches to the regulation of growth and development. In stockbreeding - increasing of the investment maintanence will stimulate the increasing and improvement of the quality of all types of livestock production, spreading the distribution of automatiozation and computerization processes, equipment improvement of livestock farms and complexes, providing proper welfare of farm animals and poultry, improvement of balanced feeding.

Sustainable development of the agricultural sector will increase the volume of gross agricultural products and its processed products, improve its quality, increase its standarts sccording with modern tastes and preferences of consumers, optimize the consumption of agricultural products and processed products in accordance with rational physiological norms. Conditions for the preservation and protection of agricultural landscapes, natural resource management, environmental improvement will be create the. Infrastructure will develop, the network of credit support investment will expand, an effective agricultural market infrastructure will be formed, a network of procurement centers, specialized companies and sales channels will develop, access for agricultural producers to the distribution channels of all the agricultural products will expand, the practice of production, servicing, consumer and other agricultural cooperation will extend. The development of social infrastructure in rural areas, improvement of socioeconomic conditions of rural communities, development of rural areas will be ensured.

\section{CONCLUSIONS}

The implementation of mechanism of investment maintenance for sustainable development of the agricultural sphere will provide stimulation and increase motivation for managing, will improve the profitability of owners of agricultural land and rural residents, will create conditions for the growth of average wages for employees of agricultural production to the average level of the the national economy, promote improve the forms and methods of human capital in rural areas particularly through information and education of the rural population, provide consolidation in rural areas of qualified personnel, and thus form a clear vector of sustainable socio-economic development of the agricultural sphere.

\section{REFERENCES}

1 Sabluk, P. - Kuril, L. (2014): Development centers in rural areas in the management of agricultural economics. Economy AIC, 5, pp. 51-56.

2 Voloshchuk, K. (2011): Mechanisms of innovation and investment development of agricultural enterprises: monograph. Kamenets: Sysyn AV.

3 Balyan, A. (2013): Problems of innovation in agriculture and ways to solve them. AV, 7-9, pp. 44-47.

4 Mazanyi, T. - Tkachenko, V. (2016): Investments in agricultural production. Agrosvit, 11, pp. 47-50.

5 Mezentsev, N. - Frost, I. (2011): Investment activity in the agro-food production of Ukraine: Regional Aspects: monograph. K.: Horizons.

6 Damyan, Ya. (2015): Methodical basis of researching the investment climate in the regions. Sustainable development: The International Journal, 3 (24), pp. 8-11.

7 Statistical information (2017): Official website of the Main Statistical Office in Utah. Available at: 〈http://uz.ukrstat.gov.ua/〉

8 Grynyk, G. (Ed.) (2011): Statistical Yearbook Transcarpathia 2010. Department of Statistics in the Transcarpathian region. Uzhgorod.

9 Demyan, Ya. (2015): Evaluation of investment attractiveness of agricultural sector. Scientific Journal of Kherson State University. Kherson

10 10.Grynyk, G. (Ed.) (2013): Statistical Yearbook Transcarpathia 2012. Department of Statistics in the Transcarpathian region. Uzhgorod. 